\title{
Ownership Structure and Non-Performing Loans: Evidence from Pakistan
}

\author{
Fawad Ahmad \\ FAST School of Management \\ National University of Computer and Emerging Sciences (FAST-NUCES) \\ Peshawar Campus, Pakistan \\ E-mail: Fawad.Ahmad@nu.edu.pk
}

Received: August 16, 2013 Accepted: November 28, 2013 Published: December 1, 2013

doi:10.5296/ajfa.v5i2.4133 URL: http://dx.doi.org/10.5296/ajfa.v5i2.4133

\begin{abstract}
The main aim of this paper is to investigate the impact of ownership structure on the bank riskiness as measured by NPLs, by using traditional view that that concentrated ownership results in enhanced banking performance by reducing the bank riskiness, whereas dispersed ownership results in the reduced banking performance and increased bank riskiness against the opposite view that ownership concentration does not have impact on the bank riskiness. By using the data from Pakistani banking sector results suggested the validity of traditional view that publically owned banks (dispersed ownership) reduces the banks performance and enhance the banks riskiness (NPLs), whereas rejected the view that concentrated ownership (privately owned banks and foreign banks) enhances bank performance and erodes the bank riskiness.
\end{abstract}

Keywords: NPLs, Ownership structure, Bank riskiness, Efficiency, Performance, Concentrated and dispersed ownership 


\section{Introduction}

The Asian financial crisis of 1997 raised various questions relating the unstable nature and risk taking tendency of Asian banks. In order to reform banking sector, Asian banks regulators proposed and implemented reform measures to ensure the stability of the banking sector. First, Asian governments discouraged the shutting down of banks by encouraging and in many cases forcing the distressed banks to merge with the safe banks (Hawkins and Turner, 1999; and Gelos and Roldos, 2004), at that time it was not confirmed that the mergers will result in the strong or weak intermediary, but it helped in improving the financial viability of the distressed banks (Hawkins and Turner, 1999). Second, few Asian governments announced bailout packages for distressed banks. These packages also enforced the banks to change their ownership structures (Hawkins and Turner, 1999). However, the government interventions to encourage mergers are much more cost-effective than bailout packages. Third, Asian governments allowed the foreign investors to own the banks in the countries in order to import best foreign banking practices, corporate governance and latest technology in the country (Choi and Dovutivate, 2004). Fourth, many Asian governments implemented the restructuring measures such as changes in corporate structure, polices, bank mangers or management. All these measures are closely related to the changing ownership structure and risk bearing tendency of banks, thus question arises here "Ownership structure has effect on bank riskiness or not?"

The banking reforms program begins immediately after 1997 and lasted till 2000. These reforms were aimed to change the ownership structure and governance of banks. The aim of this study is to check whether ownership concentration improves or do not affect the banks riskiness by using NPLs loans as measures of riskiness. How does bank riskiness is affected by ownership structure? In corporate finance literature, no concise result is given for this question. Some studies have suggested that ownership structure increases firm riskiness while other suggests that ownership has no role in reducing firm riskiness. For instance, Berle and Means (1933) concluded that dispersed ownership reduces the decision influencing power of shareholders and control over firm management. Thus risk in the firm increases because shareholders have no power to influence the firms decision making, thus management will make only those decisions which are in their own benefits, whereas concentrated ownership results in more corporate control because of increase in firm monitoring.

This paper aims at investigating the Berle and Means (1933) traditional view that concentrated ownership results in enhanced banking performance by reducing the bank riskiness against the opposite view that ownership concentration does not have impact on the bank riskiness. In this paper bank riskiness is measured by the NPLs. This paper used three measures of ownership structure i.e. publicly, privately and foreign owned banks.

\section{Literature Review}

Banks that are publicly owned have different agency problems and challenges than those of the privately owned because of the wide separation of control and ownership. In publicly owned banks ownership is widely dispersed because of which the control of owners on the mangers is relatively weak resulting in the asymmetric of information and divergence of 
incentives between managers and owners (Jensen and Meckling, 1976). On the other hand private banks are mainly characterized with centralized ownership because ownership is less dispersed and owners are having larger shares and interest in the performance of banks. Furthermore in centralized ownership owners can control the working of the mangers because of the access to the internal information and influence on the decision making.

The difference between the publicly owned and privately owned banks are not only limited to the control and management but they also differs in terms of capital market access and market discipline. In case of publically owned banks risk taking ability is affected by the market discipline because it controls the risk taking behavior of banks thus when considering risk taking incentives of banks market discipline should also be considered (Flannery, 2001; and Bliss and Flannery, 2002). Market discipline is one of the main pillars of Basel II Capital Accord. The main idea behind market discipline is to enhance the bank supervision in order to reduce the risk taking incentives of publicly owned banks and privately owned banks that mainly dependent on the debts as the primary source of funding. Public equity can be raised quickly and at lower costs as compared to the private equity. When publicly owned banks enter the market with high risk strategies, they have greater chance of raising funds as compared to their counterparts with same strategies.

According to Shleifer and Vishny (1986) the extent to which ownership is concentrated, improves the corporate control by enhancing the control and monitoring of management. In dispersed ownership no individual investor has greater stake involve in firm therefore they are not much concerned with the control and monitoring the performance of firm, whereas in concentrated firms stake of individuals or closely related group of investors are involved, the loss in value of firm will have bad effect on these investors therefore they are more concerned with the control and performance of firms.

Burket, Gromb, and Panunzi (1997) challenged the view that reduction in managerial discretion by dispersed outside ownership is always beneficial. Burket et al., (1997) suggested that the reduction in managerial discretion by dispersed outside ownership is not always beneficial, it comes with costs such as expropriation threat. They also argued that even in case of tight or concentrated outside ownership, it constitutes threat of expropriation that results in the reduction of the managerial incentives. With the reduction of managerial incentives the non-contractible investments (off-balance sheet) that mangers do for the benefits of shareholders also reduces, thus the threat of expropriation results in the reduction of firm value.

Large shareholders with concentrated majority groups are mostly the main drivers of the firms, and have different interest from minority shareholders. Gomes and Novaes (1999, 2005) concluded that conflicting groups of majority shareholders protects the interest of minority shareholders and also prevent the firms from taking efficient decisions.

Regulation of governments regarding the specific industry or sector also play important role in the working of mangers, which was studied by Demsetz and Lehan (1985), they argued that the strong regulation regarding specific industries such as financial sector, play important role in regulating the discipline and decisions of mangers, resulting in the reduced benefits of 
ownership structure. Elyasiani and Jia (2008) supported the findings of Demsetz and Lehan (1985) and further concluded that institutional supervision can replace the owners monitoring of firms. The existing literature has also focused the risk taking ability of the publicly and privately owned banks. For instance, Nichols, Wahlen, and Wieland (2009) suggested that publicly owned banks generally has more loan losses and loan losses provisions than privately owned banks.

The existing literature has suggested that the risk taking ability and agency problems varies in firms with the nature of ownership. Among agency problems first issue was identified by Jensen and Meckling (1976) known as conflict of interest, which suggests the diversified shareholders are willing to take higher risks to increase their earnings whereas mangers tries to reduce risk exposures and losses, in order to save their positions and to serve their personal benefits (Jensen and Meckling, 1976; and Esty, 1998). One of the early empirical studies relating impact of ownership structure on bank risk taking incentives was conducted by Saunders, Strock, and Travlos (1990). They hypothesized that stock holder controlled banks have greater incentives to take risks as compared to the privately owned banks, there results supported the hypothesis and suggested positive relation between stockholder control and risk taking incentives. They also concluded that risk taking incentives and managerial control are negatively associated with each other. Like Saunders et al., (1990) other studies also found significant association between ownership and risk taking incentives but without any consistent agreement on the sign of relationship. Some studies found positive relationship, some suggested negative and few proved U-shaped or inverse U-shaped relationship. For instance, Sullivan and Spong (2007) concluded that the banks having mangers as their shareholders, the stock ownership of such banks are positively associated with the bank risk, which shows that under certain situations banks manger operates the banks for the benefits of their owners. Furthermore, Westman (2011) found that in non-traditional banks management ownership is positively associated with the profitability, whereas in traditional banks board ownership is positively associated with the profitability.

Existing literature has analyzed the association between ownership structure and banks performance with no concise empirical evidences on relation, furthermore theoretical explanation of the relation is also not clear. For instance Aghion and Tirole (1997) concluded that firm performance can be improved through concentrated ownership because of the increase in supervision and prevention of managerial takeovers, whereas, Shleifer and Vishny (1997) in there theoretical study argued that large shareholders can use their power to influence strategies in favor of their own benefits and can exploit the minority share holders. Boubakri and Ghouma (2010) found that expropriation by the ultimate owners affects the performance of firms bonds and ratings. Laeven and Levine (2009) found that the risk taking ability of the banks increases with powerful owners. Later on $\mathrm{Haw}, \mathrm{Ho}, \mathrm{Hu}$, and $\mathrm{Wu}(2010)$ confirmed the findings of Laeven and Levine (2009) by suggesting that the concentrated ownership exhibits higher insolvency risk, poor performance and greater earnings volatility. Whereas Shehzad et al., (2010) found that when the ownership concentration is 50 percent or more than NPLs decreases, they also suggested that weak shareholder protection rights are beneficial for the ownership concentration for banks. 
The existing literature has provided evidence relating the performance comparison between publicly and privately owned banks. Agency costs in the government owned firms can results in the weak managerial rewards, under-utilization and misallocation of resources. Agency cost view illustrates that private firm's mangers do not work at their full potential as compared to private firm's counterpart and usually use most of the resources for their personal benefits. From political corruption aspects state owned banks works to serve the supporters of government, political influence in banks decreases efficiency and loan quality by allocating the funds on political basis (Khwaja and Mian, 2005). The existing studies have proved that poorer loan quality and high NPLs are mainly associated with government owned banks (Berger, Clarke, Cill, Klapper, and Udell, 2005; and Iannota, Giacomo, and Sironi, 2007). Iannota et al., (2007) also concluded that privately owned banks are more profitable than government owned and mutual banks. They also found that among mutual, private and public banks, publicly owned banks has the highest NPLs and bad loan quality whereas mutual banks has lowest NPLs and high quality loans. Furthermore, Micco, Ugo, and Monica (2007) have found that privately owned banks has the better performance than all other banks in developing countries. They also find that the state owned banks have higher costs and lower profitability as compared to the private banks, whereas opposite is the case for foreign owned banks.

Two important things must be considered while testing Berle and Means (1933) theory in the context of banking sector, first the minority shareholders protection, and second deposit holders protection. The existing studies showed that minority shareholder have no control over the firm management unless they are provided with proper legal protection (Shleifer and Vishny, 1997). Similarly La Porta, López, Shleifer, and Vishny (1998) found that ownership concentration is negatively associated with shareholder protection. Their findings are consistent with the hypothesis that small dispersed shareholders are not important in those countries where their rights are not protected. Because of these two reasons protection of minority share holders is considered in empirical model of this study.

Pathan (2008) investigated the importance of board structure of banks on their risk taking ability and used the data of USA banks and found that strong boards represented by most of share holders increases the risk appetite of banks. Whereas, CEO powered banks have little or no risk appetite. Supervisory authorities implement depositor protection rights, act in favor of depositors and protect their interests, whereas deposit insurance safeguards the wealth of the depositors. As a result depositors demand for lower interest rates, resulting in lower risk taking opportunity for banks (Demirgüç-Kunt and Huizinga, 2004).

Here the differences between the banking firm and non-financial institution must be considered. The main difference is that banks have both account holders and share holders, whereas non-financial institutions only have shareholders. Banks have to look for the benefits of both the depositors and shareholders. But in order to increase the profits shareholders together with banks mangers enter into illegal acts against the depositors by increasing the lending to the risky borrowers at higher rates. This may results in growth of NPLs and capital inadequacy (Boyd, Chang, and Smith, 1998). Further it increases moral hazards problems because neither bank nor shareholders takes the responsibility of their illegal acts. To secure 
the interest of banks supervisory authorities keep close look on the policies of banks. Park and Peristiani (2007) used the banking data to examine the moral hazard problem and investigated that bank shareholders can pursue risky strategies by using the insured deposits or not. Their results showed that strong protection rules and supervision can reduce the moral hazard problem. Therefore, role of supervisory institutions and deposits insurance are incorporated in the empirical model.

Four existing studies are closely related to the relationship between ownership structure and NPLs. Caprio et al., (2007) investigated the impact of both share holder protection laws and ownership structure on the bank valuation. They used the data of 244 banks of 44 countries. They find that in few countries where protection laws are strong banks have dispersed ownership, whereas in countries where protection laws are weak banks are family or government owned. Their results showed that ownership structure play vital role in governing of banks. Furthermore they find that owner value is boosted by controlling large cash flows of banks, share holder value increases because of the strong protection laws and right on the cash flow decreases the adverse affect of minority shareholders. This study distinguishes from Caprio et al., (2007) by using NPLs in place of the bank value.

Laeven and Levine (2009) conducted the first empirical study on theories relating the banks risk appetite, national bank regulations and ownership structures. Their study was based on investigating the impact of conflict between owners and managers over bank risk appetite. They find that comparative power of shareholders has positive impact on the risk taking ability of banks. They further proved that capital regulation, bank risk, restriction on bank activities and deposit insurance policies depends on the banks ownership structure. There are few differences between Laeven and Levine (2009) and current study. First, they used the ownership structure of $10 \%$ to $20 \%$ whereas this study uses dummy variable of publicly, privately and foreign owned banks as measures of ownership structure. Second, they used z-score as a proxy for risk whereas this study uses NPLs as proxy of bank riskiness. Third, they used data of 44 countries, but this study uses only the commercial banks data of Pakistan.

This study is similar to the study of Shehzad et al., (2010), who investigated the impact of ownership on bank riskiness (measured by NPLs and capital adequacy). They used 500 banks data from 50 countries over the period of 2005-2007. They find that concentration of ownership has negative impact on the NPLs and helps in reducing NPLs, whereas concentration of ownership has positive impact on the capital adequacy ratio. They further argued that at low level of supervisory control and protection rights, ownership structure has negative impact of riskiness. The current study differs from Shehzad et al., (2010) in three aspects, first, they have used the banks data from 50 countries but this study uses the data of Pakistani banks. Second, they have used NPLs and capital adequacy as measures of riskiness whereas this study uses only NPLs as riskiness measure. Third, their study used three measures of ownership concentration i.e. $10 \%$ or more, $25 \%$ or more and $50 \%$ or more, whereas this study uses dummy variables of publicly, privately and foreign owned banks as the measure of ownership concentration. 
Barry et al., (2011) used detailed European commercial banks ownership data to analyze the relationship between different ownership structures of privately and publicly owned banks and level of risk and profitability. They divided the ownership structure into five categories. They proved that ownership structure significantly explains the risk differences in different categories especially in private banks. They find that as the equity stake of individual or banking institution increases the assets riskiness and decreases default risk. When non-financial institutions or institutional investors are holding the highest shares then they go for the riskiest strategies. The results showed that change in ownership for the private banks have no affect on bank risk appetite. They also find that the regulation of banking supervision authorities increases the efficiency, lowers the NPLs and improves the quality of publicly held banks. The current study relates to Barry et al., (2011) in two aspects, first, Barry et al., (2011) have used five categories of ownership structure whereas this study uses three categories (public, private and foreign owned banks) because data is only available relating three categories. Second, like Barry et al., (2011) the current study also investigated the association between risk and ownership structure.

Based on existing literature current study formulated eight hypotheses relating association between NPLs and ownership structure and other related variables. The hypotheses are given below

H1: Public ownership results in the declined banking performance and increased NPLs.

H2: Private ownership results in the enhanced banking performance and decreased NPLs.

H3: Foreign ownership results in the enhanced banking performance and decreased NPLs.

H4: high investor protection (deposit holder protection) results in the decline in NPLs.

H5: High supervisory control results in the decline in NPLs.

H6: High restrictions on activities results in the decline in NPLs.

H7: High bank concentration results in the growth of NPLs.

H8: Listed or not listed bank may have positive or negative impact on the NPLs.

The research frame work of ownership structure and other literature supported variables is given below 


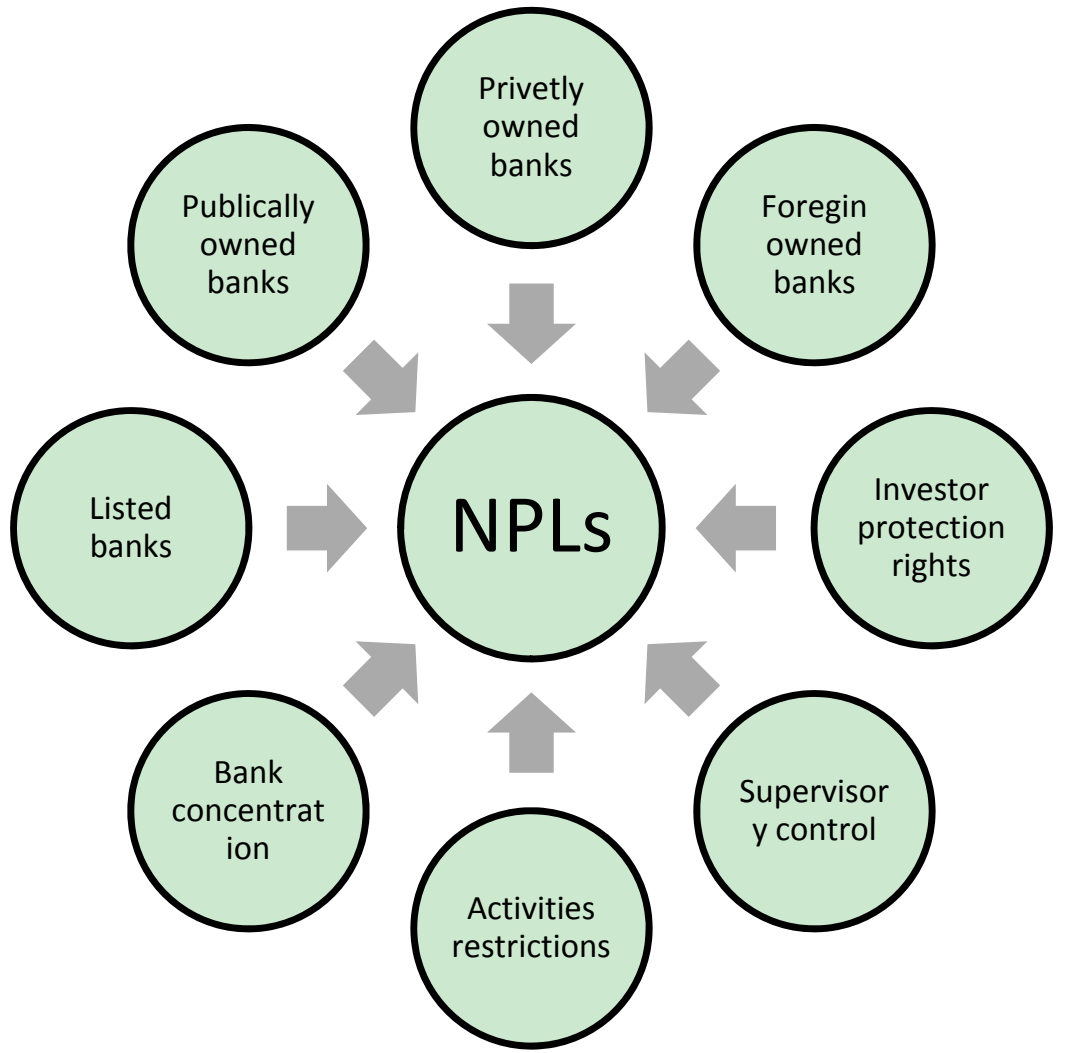

Figure 1. Ownership structure and other related variables research framework

\section{Explanatory Variables}

This study investigates the Berle and Means (1933) traditional view that concentrated ownership results in enhanced banking performance by reducing the bank riskiness against the opposite view that ownership concentration does not have impact on the bank riskiness. This study used three measures of ownership structure i.e. publicly, privately and foreign owned banks.

Djankov, La Porta, Lopez-de-Silanes and Shleifer (2008) used Investor protection index (IPI) to account for the shareholder protection rights in their model. Following Djankov et al., (2008) here IPI is used as a measure of shareholder protection rights. The IPI is based on legal protection to the minority shareholder. The IPI consist of the three main dimensions: ability of shareholder to sue directors and offices, transparency maintained by the firms in transactions and self-dealing liability. The value of IPI ranges from 0 to 10 , representing low protection and high protection respectively.

The data relating the supervisory control is available on the IMF database which uses Barth et al., (2001) methodology to measure supervisory control. The Barth et al., (2001) methodology consists on a set of questions and total affirmative answers to these questions are averaged to obtain supervisory control. Detailed information relating methodology of supervisory control is available in IMF database and in Barth et al., (2001). 


\section{Macrothink}

For activities restriction, Barth, Caprio and Levine (2001) measure of activities restriction is used. This measure consists of a set of questions developed by Barth et al., (2001). The data relating this measure is available on the World Bank database. It considers the restriction under which banks are engage in insurance, real estate and securities activities. Its value is in range of 0 (low restriction) to 4 (high restriction).

This study uses Beck, Demirgüç-Kunt and Levine (2000) measure of bank concentration, its data in available on the World Bank database. Bank concentration is measure of the three largest bank assets as a percentage of all banks assets in a country. This measure is also available on SBP website.

The ownership concentration and other literature supported variables, there literature supported relation with NPLs and references are given in table 1.

Table 1. Explanatory variables, literature supported relations, data source and references

\begin{tabular}{|c|c|c|c|}
\hline Variables & $\begin{array}{l}\text { Relation } \\
\text { with } \\
\text { NPLs }\end{array}$ & Data source & References \\
\hline $\begin{array}{l}\text { Ownership } \\
\text { concentration }\end{array}$ & $+/-$ & SBP & $\begin{array}{l}\text { Caprio et al., 2007; and Barry et al., } \\
2011\end{array}$ \\
\hline $\begin{array}{l}\text { Investor } \\
\text { Protection } \\
\text { Index }\end{array}$ & - & www.doingbusiness.org & $\begin{array}{l}\text { Caprio et al., 2007; and Shehzad et al., } \\
2010\end{array}$ \\
\hline $\begin{array}{l}\text { Supervisory } \\
\text { control }\end{array}$ & - & IMF & $\begin{array}{l}\text { Barth et al., 2001; Laeven and Levine } \\
\text { 2009; and Shehzad et al., } 2010\end{array}$ \\
\hline $\begin{array}{l}\text { Activities } \\
\text { restrictions }\end{array}$ & + & World Bank & $\begin{array}{l}\text { Barth et al., 2001; Laeven and Levine } \\
\text { 2009; and Shehzad et al., } 2010\end{array}$ \\
\hline $\begin{array}{l}\text { Bank } \\
\text { concentration }\end{array}$ & + & SBP & $\begin{array}{l}\text { Beck et al., 2000; Laeven and Levine, } \\
\text { 2009); and Shehzad et al., } 2010\end{array}$ \\
\hline Listed banks & $+/-$ & $\begin{array}{l}\text { Karachi } \\
\text { Exchange }\end{array}$ & Shehzad et al., (2010) \\
\hline
\end{tabular}




\section{Data and Procedures}

This section used panel data of commercial banks currently operating in Pakistan. For each bank 5 years data is collected. Currently there are 34 commercial banks operating in Pakistan which can be divided into three broad categories i.e., public sector, private sector and foreign banks. Out of 34 banks 30 banks fulfilled the data requirement. The data relating the bank concentration and dependent variable was collected from the SBP publication "Financial Statement analysis of the Financial Sector 2006-2009" and annual reports of commercial banks for the year 2010 given on SBP website. The variables such as ownership concentration data is collected from publication "Financial Statement analysis of the Financial Sector 2006-2009", there the names of publicly, privately and foreign owned commercial banks are given. The data on IPI is collected form "www.doingbusiness.org", data on activities restriction is collected form World Bank data base and supervisory control data is collected form IMF data base.

At first random effect model is applied, after that Hausman random effect test is run to check the validity of random effect model, in results Chi-square statistics and its corresponding $\mathrm{p}$-value is used to predict whether random effect model is valid or not. After getting the results of random or fixed effect, model is checked for its prediction ability by using certain features and characteristics. First model R-squared value with number of significant relation and F-statistics value is checked; commonly high R-squared value with maximum number of significant relations and $\mathrm{F}$-statistics value with $\mathrm{p}$-value less than $5 \%$ are considered best. Second, residual correlation is checked by using Durbin-Watson statistics, commonly when its value is 2 or around 2 then there is no correlation.

The model of the ownership structure and other related variables is given as follows

$$
N P L s_{i t}=\beta_{1}+\beta_{2} O C_{i t}+\beta_{3} I P I_{i}+\beta_{4} S C_{i}+\beta_{5} A R_{i t}+\beta_{6} B C_{i t}+\beta_{7} \text { Listed or not }_{i t}+\omega_{i t}
$$

Where

$N P L s_{i t}$ is the dependent variable, banks riskiness (impaired loans to gross loans ratio) in time period " $t$ " for cross-recessional unit " $i$ "

$O C_{i t}$ is the ownership concentration (publically, privately and foreign owned banks) in time period " $t$ " for cross-recessional unit " $i$ "

$I P I_{i}$ is the investor protection index for cross-recessional unit " $i$ "

$S C_{i}$ is the supervisory control for cross-recessional unit " $i$ "

$A R_{i}$ is activities restriction for cross-recessional unit " $i$ "

$B C_{i}$ is the bank concentration for cross-recessional unit " $i$ "

Listed or not Indicates whether bank is listed or not

$\beta_{1}$ is the intercept mean value with $\varepsilon_{l}$ individual intercept deviations from mean value 
$\beta_{2}, \beta_{3}, \beta_{4}, \beta_{5}, \beta_{6}$ and $\beta_{7}$ are the respective co-effcient terms

" $\omega_{i t}$ " is the composite error term including $\varepsilon_{t}$ is individual unit error component and $\mu_{i t}$ is combined time and units error component.

" $i$ " is the cross section units (30 banks)

" $t$ " is the time period (2006 to 2010)

\section{Results and Analysis}

The analysis of ownership structure and other related variables starts with the selection of ownership structure and other related variables. Eight hypotheses are formulated for ownership structure and other related variables.

The random effect model is applied by using eight explanatory variables; the results of random effect model are given in table 15. The fitness of the model is predicted with the help of R-squared, F-statistics and number of significant relationship between NPLs and explanatory variables. The R-squared value for the model is 0.608551 , suggesting that almost $60 \%$ variance in NPLs are explained by eight ownership structure and other related variables. The F-statistics of the model has a p-value of 0.08542 , suggesting that eight variables can not influence the NPLs jointly. 


\section{1) Macrothink}

Asian Journal of Finance \& Accounting

ISSN 1946-052X

2013, Vol. 5, No. 2

Table 2. Random effect model results of ownership structure and other related variables

\begin{tabular}{|c|c|c|c|c|}
\hline Variable & Coefficient & Standard error & t-Statistic & Probability \\
\hline Publically owned banks & 0.0328941 & 0.0355429 & 0.9255 & 0.35633 \\
\hline Privately owned banks & 0.0078972 & 0.0320113 & 0.2467 & 0.80551 \\
\hline Foreign owned banks & -0.03762 & 0.026471 & -1.421191 & 0.1788 \\
\hline Investor protection rights & -0.0535625 & 0.0409358 & -1.3085 & 0.19290 \\
\hline Supervisory control & 0.00962676 & 0.0111343 & 0.8646 & 0.38876 \\
\hline Activities restrictions & -0.65926 & 1.27521 & -0.5170 & 0.60600 \\
\hline Bank concentration & 0.71676 & 0.645235 & 0.867675 & 0.0186 \\
\hline Listed banks & 0.0169231 & 0.0267529 & 0.6326 & 0.52806 \\
\hline $\mathrm{C}$ & 0.548537 & 0.46921 & 1.1691 & 0.24439 \\
\hline R-squared & 0.608551 & & & \\
\hline Adjusted R-squared & 0.391080 & & & \\
\hline F-statistic & 2.79830 & & & \\
\hline P-value & 0.08542 & & & \\
\hline
\end{tabular}

After applying random effect model, hausman random effect test is run to check the validity of random effect model, in results Chi-square statistics and its corresponding p-value is used to predict whether random effect model is valid or not. When p-value of Chi-square statistics is less than 1 then it shows that random effect model is not appropriate and fixed effect model is preferred. If the p-value is less than 1 then fixed effect model will be used. The results of the hausman random effect test are given in table 3. 
Table 3. Hausman random effect test

\begin{tabular}{|l|l|l|}
\hline Test Summary & Chi-Square Statistic & Probability \\
\hline Cross-section random & 3.30351 & 0.769901 \\
\hline
\end{tabular}

The results suggest that the p-value for the Chi-square statistics is 0.769901 , which is less than 1. This shows that random effect model is not valid and does not provide the preferred specification of the variables used in the analysis; therefore variables are regressed again by using fixed effect model. The result of fixed effect model is given in table 4.

The fixed effect model is applied by using eight explanatory variables; the results of random effect model are given in table 4. The fitness of the model is predicted with the help of R-squared, F-statistics and number of significant relationship between NPLs and explanatory variables. The R-squared value for the model is 0.568181 , suggesting that almost $57 \%$ variance in NPLs are explained by eight ownership structure and other related variables. The F-statistics of the model has a p-value of 0.363237 , suggesting that eight variables can not influence the NPLs jointly. 


\section{MInstitute ${ }^{\text {Mink }}$}

Asian Journal of Finance \& Accounting

ISSN 1946-052X

2013, Vol. 5, No. 2

Table 4. Fixed effect model results of ownership structure and other related variables

\begin{tabular}{|c|c|c|c|c|}
\hline Variable & Coefficient & Standard error & t-Statistic & Probability \\
\hline Publically owned banks & 0.05124 & 0.024705 & 2.074100 & 0.06791 \\
\hline Privately owned banks & 0.0230583 & 0.0379835 & 0.6071 & 0.56297 \\
\hline Foreign owned banks & -0.03362 & 0.025475 & -1.191191 & 0.2388 \\
\hline Investor protection rights & 0.0164891 & 0.0481341 & 0.3426 & 0.74198 \\
\hline Supervisory control & 0.00962676 & 0.0111343 & 0.8646 & 0.38876 \\
\hline Activities restrictions & 0.60026 & 1.27821 & 0.4670 & 0.50600 \\
\hline Bank concentration & -3.1848 & 1.46809 & -2.1693 & 0.06668 \\
\hline Listed banks & 0.011575 & 0.0465201 & 0.2488 & 0.81064 \\
\hline $\mathrm{C}$ & 1.02908 & 0.64114 & 1.6051 & 0.15251 \\
\hline R-squared & 0.568181 & F-statistic & 1.315786 & \\
\hline Adjusted R-squared & 0.136362 & P-value & 0.363237 & \\
\hline Durbin-Watson statistics & 2.224787 & & & \\
\hline
\end{tabular}

The results provide only two significant relations whereas remaining six variables have insignificant association with NPLs. The results suggest significant positive association between the NPLs and public (dispersed) ownership.

The existing studies have also found the positive association between NPLs and publically owned or dispersed ownership (Shleifer and Vishny, 1986; Berger et al., 2005; Iannota et al., 2007; and Nichols et al., 2009). The results of current study confirms the validity of traditional view of Berle and Means (1933) that dispersed ownership has negative impact on the efficiency and performance of the banks and with dispersed ownership control and supervision on the firm declines results in the growth of firm riskiness.

The positive relation confirms that in publicly owned banks (dispersed ownership) the control of the owners on the mangers is weak, resulting in the asymmetry of information and conflict 
of interest between owners and managers (Jensen and Meckling, 1976), leading to the decisions that are in benefit to managers. Due to less supervision and control, mangers increase the riskiness of the loan portfolio in order to improve the short term cost efficiency. They lend money to the low quality borrowers, resulting in the growth of future NPLs. In publically owned banks level of supervision and monitoring is very weak (Shleifer and Vishny, 1986), because stake of large number of dispersed investor is involved. As the stake of individual investor is small therefore they pay less attention on the working and risk exposure of the banks.

Corruption also play important role in the growth of NPLs in the publically owned banks. In country like Pakistan regulatory and supervisory authorities are very weak in regulating and implementing laws, due to which lenders take advantage and do not repay loans because they know that no strong legal action will be taken against them because of this the rate of NPLs in public banks are on the higher side. The other reason for the increase in NPLs is the corruption in the political system of the country. Most of the time political owned firms lend funds from the banks and by using the political power and corrupt practices do not repay loan (Khwaja and Mian, 2005). Furthermore the management of the banks also by using corrupt practices lends money to low quality borrowers (Barth, Lin, Lin and Song, 2009), which results in the increase in NPLs.

The other main reason for the positive relation between NPLs and publically owned banks is the lenient credit policies and inefficiency of the credit evolution departments of the banks; because public banks lend money to those who are ready to pay more than others and do not take collaterals rather lend funds on the warranties and political status. Due to all these reason publically owned banks has high rate of NPLs than other banks (Micco et al., 2007). The positive relation also confirms the findings of Saunders et al., (1990) that in publically owned banks managers can take higher risks due to the weak supervision and monitoring. This results in the increase in loan portfolio riskiness and thus results in the growth of future NPLs.

The results of current study reject the traditional view of Berle and Means (1933) that concentrated ownership (private ownership) has positive impact on the efficiency and performance of the banks and with concentrated ownership control and supervision on the firm increases, resulting in the achievement of owner's goal. The justification for the positive relation can be that in private owned banks control of the owners on the management is strong, thus owners can influence the risk taking decision of the management and can force the management to increase the riskiness of the loan portfolio by lending funds to the low quality borrowers (Saunders et al., 1990; Laeven and Levine, 2009), resulting in the future growth of NPLs. The results of current study confirm the traditional view of Berle and Means (1933) in case of foreign ownership that concentrated ownership has positive impact on the efficiency and performance of the banks. They further suggested that with concentrated ownership control and supervision on the firm increases resulting in the decline of firm riskiness (Shleifer and Vishny, 1986). 
The current study suggests that with the increase in protection to the investors the NPLs increases. This result is opposite to the findings of existing study that with the increases in investor protection rights bad loans declines. The justification of the negative relation is the weak and corrupt legal institution of Pakistan that fails to implement the laws and regulations, because of which low quality borrowers defaults the loans with out any fear legal actions.

The current study provides the expected sign between the NPLs and supervisory control. The association between NPLs and supervisory control as given by table 4 is insignificant, suggesting that supervisory control does not have significant influence in decreasing the level of NPLs. The result suggests that as the supervisory control over the banks in the from of supervision by the regulatory authorities increases then banks follow the standard procedures for the allocations of loan and thus the possibility of lending to the low quality borrowers decreases, resulting in the decline of NPLs.

The results in table 4 provide insignificant positive association between NPLs and activities restrictions. The results reject the $\mathrm{H} 6$ of the current study that activities restriction results in the decline of NPLs. The justification for the positive sign is that the laws and rules are improving every day in Pakistan, but the main problem is the implementation of the rules and laws. Countries like Pakistan has several laws for each and every department of the banks, but regulatory and supervisory authorities are very weak because of which they do not implement the laws and regulation in there complete form. They failed to implement all the rules and laws because of the corruption, both at the macro level and inside banks and supervisory authorizes. This is the reason because of which with the increase in the strength of legal rights NPLs also increases.

The results reject the $\mathrm{H} 7$ by providing significant negative association between NPLs and bank concentration. This suggests that with the increase in the bank concentration results in the decline of NPLs. The bank concentration increases when the assets of 3 largest banks of the country increase. With the increase in assets the operations of 3 banks are diversified to different other sectors, this results in the reduction of bank risk and lending to the quality borrowers of other sectors. The risk of the banks reduces because the bad performance in one sector can be compensated by good performance of other sectors, resulting in the decline of the NPLs through diversification.

The results in table 4 suggest positive association between listed or not listed banks. The association between both is insignificant therefore the bank is listed or not has no significant impact on the NPLs. This result suggests that listed banks management in order to show short term cost efficiency, invest less on the allocation, supervision and monitoring activities of loans which results in the allocation of loans to the low quality borrowers, which results in the growth of NPLs.

The correlation of the residual of the model is checked by using Durbin-Watson statistics. The general rule for the Durbin-Watson statistics is that if its value is 2 or around 2 than the residual is not serially correlated whereas if its statistics is less than 2 than the residual is positively correlated and less than 4 represents the negative correlation. The Durbin-Watson 
statistics for the model is given in table 4; the statistics is 2.224787 suggesting that residual is not serially correlated because statistics is around the 2 .

\section{Conclusions, Policy Related Implications and Future Research}

The analysis of ownership structure and other related variables starts with the selection of ownership structure and other related variables. Eight hypotheses was formulated for ownership structure and other related variables.

The current study used eight variables relating ownership structure and related variables and applied fixed effect model. The results provided only two significant associations of publically owned banks and bank concentration with NPLs, whereas remaining six variables were insignificantly associated with NPLs. The current study investigated the Berle and Means (1933) traditional view that concentrated ownership results in enhanced banking performance by reducing the bank riskiness against the opposite view that ownership concentration does not have impact on the bank riskiness. The results provided the validity of Berle and Means (1933) traditional view in terms of publically owned banks (dispersed ownership), that it reduces the bank performance and enhance the bank riskiness (NPLs). Whereas in case of privately owned banks and foreign banks rejects the Berle and Means (1933) view that concentrated ownership enhances bank performance and erodes the bank riskiness.

The positive association between NPLs and publically owned banks suggests that in publically owned banks supervision and monitoring of the owners over the management is very low, furthermore management show short term cost efficiency by sacrificing cost incurred on loan allocation process and corrupt practices of the management, lenient credit process and political pressures leads to the declined efficiency and performance of banks, which results in the growth of NPLs. The current study provides statistically significant positive relationship between bank concentration and NPLs. This result suggests that with the increase in bank concentration the operation of large banks are diversified; this leads to the distribution of funds among different sectors. In this way risk of the banks associated with one specific sector declines and loss of any sector is compensated by the good performance of other sector.

The finding of the ownership structure and other related variables models also have implications of the policy makers. First, SBP should consider that their supervision policies have different impact on the banks according to their nature of ownership, for instance publically owned banks are less in control of their owners as compared to the private owned banks, and therefore SBP can develop supervision policies according to ownership structure. Second, the current study provide the validity of Berle and Means (1933) in terms of dispersed ownership thus public banks performance can be improved by the constant supervision of the owners and SBP. Third, SBP should take measure to strictly supervise the credit allocation process and make sure its proper implementation in the public owned banks.

The ownership structure and other related model used only one measure of bank riskiness i.e. NPLs, Shehzad et al., 2010 used two variables as measure of bank riskiness (i.e. NPLs and 
capital adequacy). The future study in Pakistan and other developing countries can be conducted by using two or more measures of bank riskiness. Shehzad et al., 2010 in their study has used the percentage of ownership as measure for ownership structure i.e. $10 \%$ or more, $25 \%$ or more and $50 \%$ or more, whereas current study used dummy variables for the publically, privately and foreign owned banks. Thus future study can used more accurate data on the ownership structure or can further divide the ownership into more categories as done by the Barry et al., (2011). The ownership structure and other related model can also be applied by using the panel data of banks from the sample of developing and developed countries (Shehzad et al., 2011; and Barry et al., 2011).

\section{References}

Aghion, P., \& Tirole, J. (1997). Formal and real authority in organizations. Journal of Political Economy, 55, 1-27. http://dx.doi.org/10.1086/262063

Barry, T A., Lepetit, Laetitia., \& Tarazi, Amine. (2011). Ownership structure and risk in publicly held and privately owned banks. Journal of Banking and Finance, 35, 1327-1340. http://dx.doi.org/10.1016/j.jbankfin.2010.10.004

Barth, J.R., Caprio G., \& Levine R. (2001). The Regulation and Supervision of Banks Around the World. A New Database. World Bank Policy Research Working Paper No. 2588.

Beck, T., Demirgüç-Kunt, A., \& Levine, R. (2000). A new database on financial development and structure. World Bank Economic Review, 14, 597-605. http://dx.doi.org/10.1093/wber/14.3.597

Berger, A., Clarke, G., Cill, R., Klapper, L., \& Udell, G. (2005). Corporate governance and bank performance: a joint analysis of the static, selection, and dynamic effects of domestic, foreign, and state ownership. Journal of Banking and Finance, 29, 2179-2221. http://dx.doi.org/10.1016/j.jbankfin.2005.03.013

Berle, A., \& Means, G. (1933). The Modern Corporation and Private Property. MacMillan, New York.

Bliss, R., \& Flannery, M. (2002). Market discipline in the governance of US bank holding companies: monitoring vs. influencing. European Finance Review, 6(3), 361-395. http://dx.doi.org/10.1023/A:1022021430852

Boubakri, N., \& Ghouma, H. (2010). Control/ownership structure, creditor rights protection, and cost debt financing: international evidence. Journal of Banking and Finance, 34, 2481-2499. http://dx.doi.org/10.1016/j.jbankfin.2010.04.006

Boyd, J.H., Chang, C., \& Smith, B.D. (1998). Moral hazard under commercial and universal banking. Journal of Money, Credit and Banking, 30, 426-468. http://dx.doi.org/10.2307/2601249

Burkart, M., Gromb, D., \& Panunzi, F. (1997). Large shareholders, monitoring and the value of the firm. Quarterly Journal of Economics, 112, 693-728. http://dx.doi.org/10.1162/003355397555325 
Caprio, G., Laeven, L., \& Levine, R. (2007). Governance and bank valuation. Journal of Financial Intermediation, 16, 584-617. http://dx.doi.org/10.1016/j.jfi.2006.10.003

Choi, D.F., \& Clovutivat, W. (2004). The relaxation of foreign ownership limits and market integration: The case of Thailand. Managerial Finance, 30, 78-89. http://dx.doi.org/10.1108/03074350410769182

Demirgüç-Kunt, A., \& Huizinga, H. (2004). Market discipline and deposit insurance. Journal of Monetary Economics, 51, 375-399. http://dx.doi.org/10.1016/j.jmoneco.2003.04.001

Demsetz, H., \& Lehen, K. (1985). The structure of corporate ownership: causes and consequences. Journal of Political Economy, 93, 1155-1177. http://dx.doi.org/10.1086/261354

Djankov, S., La Porta, R., Lopez-de-Silanes, F., \& Shleifer, A. (2008). The law and economics of self-dealing. Journal of Financial Economics, 88, 430-465. http://dx.doi.org/10.1016/j.jfineco.2007.02.007

Djankov, S., McLiesh, C., \& Shleifer, A. (2007). Private credit in 129 countries. Journal of Financial Economics, 84, 299-329. http://dx.doi.org/10.1016/j.jfineco.2006.03.004

Elyasiani, E., \& Jia, J.J. (2008). Institutional ownership stability and BHC performance. Journal of Banking and Finance, 32, 1767-1781. http://dx.doi.org/10.1016/j.jbankfin.2007.12.010

Esty, B. (1998). The impact of contingent liability on commercial bank risk taking. Journal of Financial Economics, 47, 189-218. http://dx.doi.org/10.1016/S0304-405X(97)00043-3

Flannery, M.J. (2001). The faces of market discipline. Journal of Financial Services Research, 20 (2-3), 107-119. http://dx.doi.org/10.1023/A:1012455806431

Gelos, G., \& Roldós, J. (2004). Consolidation and market structure in emerging market banking systems. Emerging Market Review, 5, 39-59. http://dx.doi.org/10.1016/j.ememar.2003.12.002

Gomes, A.R., \& Novaes, W. (1999). Multiple Large Shareholders in Corporate Governance. Working Paper. The Wharton School, Philadelphia, PA.

Gomes, A.R., \& Novaes, W. (2005). Sharing of Control as a Corporate Governance Mechanism. PIER Working Paper No. 01-029.

Haw, I.-M., Ho, S., Hu, B., \& Wu, D. (2010). Concentrated control, institutions, and banking sector: an international study. Journal of Banking and Finance, 34, 485-497. http://dx.doi.org/10.1016/j.jbankfin.2009.08.013

Hawkins, J., \& Turner, P. (1999). Bank restructuring in practice: An overview, BIS Policy Paper, 6. 
Iannotta, G., Giacomo, N., \& Sironi, A. (2007). Ownership structure, risk and performance in the European banking industry. Journal of Banking and Finance, 31, 2127-2149. http://dx.doi.org/10.1016/j.jbankfin.2006.07.013

Jensen, M.C., \& Meckling,W.H. (1976). Theory of the firm: managerial behavior, agency cost and ownership structure. Journal of Financial Economics, 3, 305-360. http://dx.doi.org/10.1016/0304-405X(76)90026-X

Khwaja, A I., \& Mian, Atif., (2005). Lenders Favor Politically Connected Firms? Rent Provision in an Emerging Financial Market. The Quarterly Journal of Economics, 120(4), 1371-1411. http://dx.doi.org/10.1162/003355305775097524

La Porta, R., López-de-Silanes, F., Shleifer, A., \& Vishny, R.W. (1998). Law and finance. Journal of Political Economy, 106, 1113-1155. http://dx.doi.org/10.1086/250042

Laeven, L., \& Levine, R. (2009). Bank governance, regulation and risk taking. Journal of Financial Economics, 93, 259-275. http://dx.doi.org/10.1016/j.jfineco.2008.09.003

Micco, A., Ugo, P., \& Monica, Y. (2007). Bank ownership and performance: Does politics matter? Journal of Banking and Finance, 31, 219-241. http://dx.doi.org/10.1016/j.jbankfin.2006.02.007

Nichols, D., Wahlen, J., \& Wieland, M. (2009). Publicly-traded versus privately-held: implications for conditional conservatism in bank accounting. Review of Accounting Studies, 14, 88-122. http://dx.doi.org/10.1007/s11142-008-9082-3

Park, S., \& Peristiani, S. (2007).Are bank shareholders enemies of regulators or a potential source of market discipline?. Journal of Banking and Finance, 31, 2493-2515. http://dx.doi.org/10.1016/j.jbankfin.2006.10.025

Pathan, S. (2009). Strong boards, CEO power and bank risk-taking. Journal of Banking and Finance, 33, 1340-1350. http://dx.doi.org/10.1016/j.jbankfin.2009.02.001

Saunders, A., Strock, E., \& Travlos, N. (1990). Ownership structure, deregulation, and bank risk taking. Journal of Finance, 45(2), 643-654. http://dx.doi.org/10.1111/j.1540-6261.1990.tb03709.x

Shehzad, C.T., De Haan, J., \& Scholtens, B. (2010). The impact of ownership concentration on impaired loans and capital adequacy. Journal of Banking and Finance, 34, 399-408. http://dx.doi.org/10.1016/j.jbankfin.2009.08.007

Shleifer, A., \& Vishny, R.W. (1986). Large shareholders and corporate control. Journal of Political Economy, 94, 461-488. http://dx.doi.org/10.1086/261385

Shleifer, A., \& Vishny, R.W. (1997). A survey of corporate governance. Journal of Finance, 52, 737-783. http://dx.doi.org/10.1111/j.1540-6261.1997.tb04820.x

Westman, H. (2011). The impact of management and board ownership on profitability in banks with different strategies. Journal of Banking and Finance, http://dx.doi.org/10.1016/j.jbankfin.2011.05.013 
Sullivan, R., \& Spong, K.R. (2007). Managerial wealth, ownership structure, and risk in commercial banks. Journal of Financial Intermediation, 16, 229-248. http://dx.doi.org/10.1016/j.jfi.2006.12.001 